\title{
Genetic Characteristics of Streptomycin-resistant Streptococci
}

\author{
By D. PERRY \\ Department of Microbiology, Northwestern University Medical School, \\ Chicago, Illinois, U.S.A.
}

(Accepted for publication 18 November 1970)

\begin{abstract}
SUMMARY
The genetic properties of transformable (SR $5 \mathrm{a}$ ) and non-transformable (SR 30) streptomycin-resistant streptococci were examined. In mutant SR 30, the very high resistance (VHR) phenotype appeared to be due to at least two factors; a high resistance (HR) mutation and an enhancing modifier gene. In mutant SR 5a, resistance was due to a single VHR mutation which is allelic to the HR mutation of mutant SR 30. The transfer of non-transformability (Ntr) by SR 30 DNA revealed that this factor is separable from the streptomycin resistance marker and the enhancing modifier. Results indicate co-transfer of Ntr with the HR marker.
\end{abstract}

\section{INTRODUCTION}

Transformability is a property of certain species of bacteria which endows them with the ability to incorporate deoxyribonucleic acid (DNA) and undergo genetic transformation. Although considerable knowledge has been gained concerning the mechanism of transformation, there is little evidence which substantially differentiates the properties of transformable bacteria from those of non-transformable strains of the same species. In recent years, attempts to define the properties of transformable bacteria have involved the use of weakly or non-transformable strains which were naturally occurring or directly derived from the transformable strain. A number of such mutants of several species of transformable bacteria have been studied in efforts to correlate certain properties with transformability (Young \& Spizizen, I96r; Pakula \& Walczak, I963; Okubo \& Romig, 1966). Subsequently, several investigators noted an alteration in transformability upon acquisition of antibiotic resistance (Sirotnak, Lunt \& Hutchison, 1963; Ephrati-Elizur, 1965; Perry, 1968). In each case, however, the possible correlation between antibiotic resistance and loss of transformability was questionable. Thus the possibility remained that the antibiotic simply selected out mutants with altered transformability from a population of transformable cells. Even so, this system has been a valuable tool for acquiring such non-transformable mutants. In addition, antibiotic resistance could be used as a marker for genetically characterizing these mutants. In this regard, we have isolated several highly resistant streptomycin mutants of transformable group $\mathbf{H}$ streptoccocus, strain CHALLIS (Perry, I968). Two of these mutants were highly transformable (SR 5a) and non-transformable (SR 30) when exposed to DNA from a novobiocin-resistant CHALLIS strain. The alteration in transformability of mutant SR 30 was found to be due to a loss in capacity to take up DNA (Perry, 1968).

The present investigation is concerned with the genetic characterization of trans- 
formable and non-transformable streptomycin-resistant streptococci. Results show that streptomycin resistance in mutant SR $5 \mathrm{a}$ is due to a single resistance mutation whereas resistance in mutant SR 30 is due to an enhancing modifier in addition to a resistance mutation. Co-transfer of non-transformability with the streptomycin resistance marker of mutant SR 30 was also demonstrated.

\section{METHODS}

Bacterial strains, DNA preparation, media and transformation procedures have been described (Perry, 1968). The mutants employed in these experiments were purified by re-streaking on a medium containing $30 \mathrm{mg} . / \mathrm{ml}$. of streptomycin until each gave I $00 \%$ plating efficiency when compared to growth on medium not containing streptomycin. The transformability of these 'purified' mutants was the same as that of the previously described mutants.

Although the majority of experiments were carried out with freshly prepared competent cells, a number were performed with competent cells which had been stored at $-70^{\circ}$ in $10 \%$ glycerine (Fox \& Hotchkiss, 1957). These cells were thawed in an ice bath before exposure to DNA.

There was no significant difference in the results when either of the two cell preparations was used. Transformation experiments are described as the DNA recipient strain $\times$ the DNA donor strain. For example, in the cross CHALLIS $\times$ SR 30 , CHALLIS is the recipient and SR 30 is the donor.

\section{RESULTS}

Level of streptomycin resistance in SR $5 a$ and $S R 30$ transformants. Competent CHALLIS cells were exposed to DNA (I $\mu \mathrm{g}$. $/ \mathrm{ml}$.) from mutant SR $5 \mathrm{a}$ or SR 30 for $15 \mathrm{~min}$. and deoxyribonuclease (DNase) was added. After allowing a further $2 \mathrm{~h}$. incubation for phenotypic expression, appropriate dilutions of the cells were spread on media containing concentrations of streptomycin ranging from 0.1 to $30 \mathrm{mg} . / \mathrm{ml}$. As shown in Table $\mathrm{I}$, the plating efficiency of SR 5a transformants was approximately the same on 0.1 or $30 \mathrm{mg} . / \mathrm{ml}$. of streptomycin. In the case of SR 30 transformants, however, two classes were apparent. Approximately equal numbers of SR 30 transformants grew on concentrations of streptomycin ranging from 0.1 to $5.0 \mathrm{mg} . / \mathrm{ml}$. At 10 and $20 \mathrm{mg}$./ $\mathrm{ml}$. of streptomycin, two different sizes of colonies appeared: the majority was very small and difficult to observe, particularly on the $20 \mathrm{mg}$. plates. The remainder of the colonies were of normal size, identical to those which grew at lower streptomycin concentrations, and considerably fewer in number (approximately Ioo-fold less). Only normal size colonies were countable on $30 \mathrm{mg}$. streptomycin plates, although slight areas of $\alpha$-hemolysis indicated the presence of some minute colonies. A number of the smaller colonies which were isolated from the 10 and $20 \mathrm{mg}$. streptomycin plates were of normal size when re-streaked onto blood agar or lower concentrations of streptomycin. Henceforth, those colonies which were of normal size on $5 \mathrm{mg} . / \mathrm{ml}$. of streptomycin, but not $30 \mathrm{mg}$., will be designated as high-resistant (HR), whereas those colonies which were of normal size on $30 \mathrm{mg} . / \mathrm{ml}$. of streptomycin will be designated as very high resistant (VHR). It should be noted that Ravin \& Mishra (1965) used similar designations in classifying various streptomycin-resistant mutants of streptococci and pneumococci. In succeeding experiments, HR and VHR transformants were selected on $0 . I$ and $30 \mathrm{mg} . / \mathrm{ml}$. of streptomycin, respectively. 
Effect of second exposure of HR transformants to SR 30 and SR 30 transformant $D N A s$. The purpose of these experiments was to determine whether the VHR phenotype of mutant SR 30 was due to one or more different HR markers. Therefore, several HR transformants were isolated from the cross CHALLIS $\times$ SR 30 , and treated with DNA from two of these isolates, HR I and HR 2. If the SR 30 phenotype is due to recombination between different $H R$ markers, any one of the $H R \times H R$ crosses should result in the formation of VHR transformants. As seen in Table 2, however, colonies of the VHR phenotype were not detected when such crosses were made. That is, no transformants appeared on $30 \mathrm{mg}$. streptomycin plates. Furthermore, DNA from the HR I and HR 2

Table I. Growth of $S R 5 a$ and $S R 30$ transformants on increasing concentrations of streptomycin

$\begin{array}{ccl}\begin{array}{c}\text { Streptomycin } \\ \text { (mg./ml.) }\end{array} & \text { SR5a DNA } & \begin{array}{c}\text { Number of transformants/10 } \\ \text { colony-forming units (CFU)* }\end{array} \\ 0.1 & 250 \times 10^{2} & 457 \times 10^{2} \\ 0.5 & - & 629 \times 10^{2} \\ 1.0 & - & 596 \times 10^{2} \\ 5.0 & - & 496 \times 10^{2} \\ 10.0 & - & 429\left(442 \times 10^{2}\right) \dagger \\ 20.0 & 261 \times 10^{2} & 464\left(329 \times 10^{2}\right) \dagger \\ 30.0 & & 418\end{array}$

Competent CHALLIS cells were exposed to DNA (I $\mu \mathrm{g} . / \mathrm{ml}$.) from mutant SR5a or SR3o for I $5 \mathrm{~min}$. DNase was added and then a further $2 \mathrm{~h}$. incubation was allowed for phenotypic expression. Appropriate dilutions of the cells were plated on different concentrations of streptomycin.

$\dagger$ Numbers in parentheses represent smaller colonies which were barely visible.

- Not tested.

Table 2. Transformation of $S R 30$ HR transformants with $D N A$ from $S R 30$ or $S R 30$ transformant

\begin{tabular}{|c|c|c|c|c|c|c|c|c|}
\hline \multirow[b]{3}{*}{$\begin{array}{l}\text { DNA } \\
\text { recipients }\end{array}$} & \multicolumn{8}{|c|}{ DNA donors } \\
\hline & \multicolumn{2}{|c|}{ HR I } & \multicolumn{2}{|c|}{$\mathrm{HR}_{2}$} & \multicolumn{2}{|c|}{ VHR* } & \multicolumn{2}{|c|}{ SR 30} \\
\hline & $0.1 \ddagger$ & 30 & O.I & 30 & O.I & 30 & 0.1 & 30 \\
\hline HR I* & - & 0 & - & 0 & - & 163 & - & 2 II \\
\hline $\mathrm{HR}_{2} \S$ & - & 0 & - & 0 & - & 0 & - & 0 \\
\hline $\mathrm{HR}_{3}$ & 一 & 0 & - & 0 & - & 195 & - & 149 \\
\hline $\mathrm{HR}_{4}$ & - & 0 & - & 0 & - & 248 & - & 217 \\
\hline HR 5 & - & 0 & - & 0 & - & 97 & - & 105 \\
\hline CHALLIS & $153 \dagger$ & 0 & I 85 & 0 & 215 & I8 & 334 & 5 \\
\hline
\end{tabular}

* The HR and VHR transformants were isolated from the cross CHALLIS $\times$ SR 30 .

$\dagger$ The numbers within the table represent transformants/104 CFU.

$\ddagger$ Concentration of streptomycin (mg. $/ \mathrm{ml}$.) on which transformants were plated.

$\S$ This mutant was found to be non-transformable when tested with novobiocin-resistant CHALLIS DNA.

$-=$ Not tested.

transformants only induced the HR phenotype in strain cHALLIS. In contrast, when the same HR transformants were exposed to DNA from SR 30 or a VHR transformant, a high frequency of VHR transformants occurred. This observation can be compared 
with the results obtained when strain CHALLIS is treated with DNA from SR 30 or the VHR transformant. In this case, only a low frequency of VHR transformants (along with a high frequency of HR transformants) was obtained. Apparently, a second round of exposure of HR transformants to these DNAs results in the transfer of a factor, rarely transferred in the first round, which increases their level of resistance to streptomycin. The possibility that more than one HR marker is responsible for increased resistance in mutant SR 30 thus seemed remote, particularly since none of the HR $\times$ HR crosses yielded VHR transformants. Although only a limited number of HR transformants were examined, these results suggest the presence of an enhancing factor in mutant SR 30 (Bryan, I96I; Rotheim \& Ravin, I96I; Ravin \& De Sa, I964). Such an enhancing factor was shown by Bryan (I96I) to be an unlinked modifier gene which conferred no streptomycin resistance by itself but raised the level of resistance when combined with a resistance mutation.

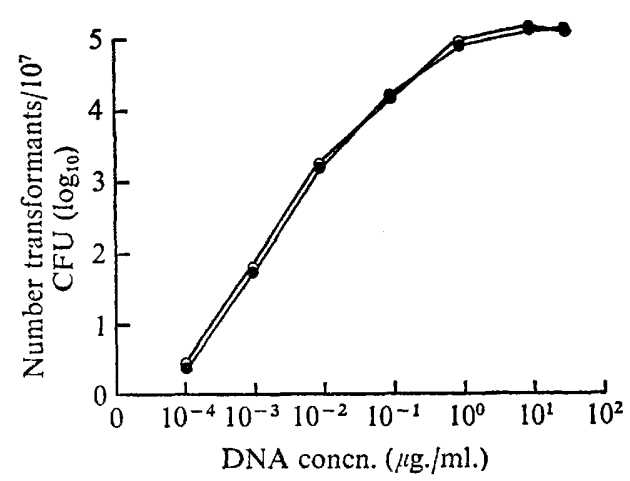

Fig. I

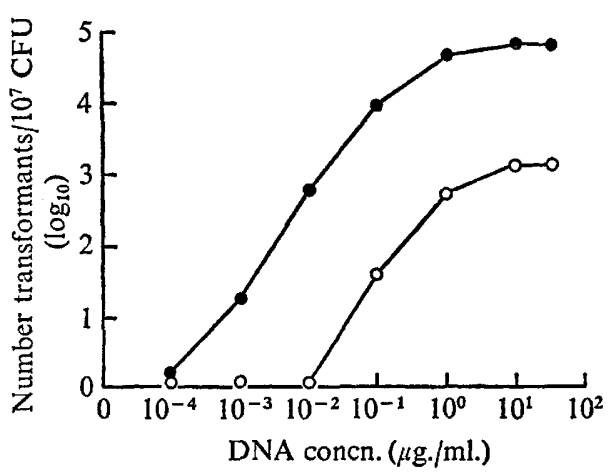

Fig. 2

Fig. I. Frequency of transformation of strain CHALLIS as a function of SR 5a DNA concentration. Cells plated on $0.1 \mathrm{mg} . / \mathrm{ml}$. of streptomycin; $O$, cells plated on $30 \mathrm{mg} . / \mathrm{ml}$. of streptomycin.

Fig. 2. Frequency of transformation of strain CHALLIS as a function of SR 30 DNA concentration. Cells plated on $0.1 \mathrm{mg} . / \mathrm{ml}$. of streptomycin; $O$, cells plated on $30 \mathrm{mg} . / \mathrm{ml}$. of streptomycin.

Effect of DNA concentration on the frequency of transformation. It can be seen in Fig. I that a typical concentration response curve resulted from the exposure of strain CHALLIS to increasing concentrations of SR 5a DNA. Throughout the entire range of DNA concentrations employed, the number of transformants which grew on 0.1 and $30 \mathrm{mg} . / \mathrm{ml}$. of streptomycin was practically identical. Furthermore, transformants selected on $0.1 \mathrm{mg} . / \mathrm{ml}$. of streptomycin exhibited $100 \%$ plating efficiency on $30 \mathrm{mg} . / \mathrm{ml}$. of streptomycin. Therefore, it appeared that transformants produced with SR 5a DNA were all of the VHR phenotype.

When strain CHALLIS was exposed to increasing concentrations of SR 30 DNA, a considerably greater number of transformants arose on the lower streptomycin concentration (Fig. 2). At DNA concentrations of $0.0 \mathrm{I} \mu \mathrm{g} . / \mathrm{ml}$. and below, no transformants were detected on $30 \mathrm{mg}$. $/ \mathrm{ml}$. of streptomycin. The ratio of transformants which arose on the lower streptomycin concentration to those on the higher concentration ranged from approximately $250(0 \cdot \mathrm{I} \mu \mathrm{g} . / \mathrm{ml}$. of DNA) to $54(\mathrm{I} 0 \mu \mathrm{g} . / \mathrm{ml}$. of DNA). This ratio of 54 did not change significantly when the DNA concentration was 
increased to $50 \mu \mathrm{g}$. $/ \mathrm{ml}$. It also should be noted that the slope of the curves are the same and that the transformants on both concentrations of streptomycin reached a plateau at the same DNA concentration. The phenotype of transformants from o. I mg. streptomycin plates was verified by replica plating (Lederberg \& Lederberg, 1952). Transformants resulting from DNA concentrations of $0.01 \mu \mathrm{g} . / \mathrm{ml}$. or less proved to be of the HR type, whereas those resulting from DNA concentrations of $0 . \mathrm{I} \mu \mathrm{g} . / \mathrm{ml}$. or greater were composed of a mixture of HR and VHR (mostly HR). Thus the frequency of VHR transformants falls off much more rapidly than the number of HR transformants as a function of decreasing DNA concentration. This observation is similar to those of others (Goodgal, I96I) suggesting that HR and the enhancing factor, as measured by the VHR phenotype, are not on the same DNA molecule in mutant SR 30 .

Frequency of transformation as a function of time of exposure to DNA. Competent CHALLIS cells were exposed to I $\mu \mathrm{g}$. $/ \mathrm{ml}$. of either SR 30 or SR 5a DNA and, at the times indicated, DNase was added. After allowing an additional $2 \mathrm{~h}$. incubation for phenotypic expression, transformants were selected on $0 . \mathrm{I}$ and $30 \mathrm{mg} . / \mathrm{ml}$. of streptomycin. Upon exposure of strain CHALLIS to SR 30 DNA, a rapid increase in the number of HR transformants $(30 \%$ of the maximum) occurred within the first 5 min. (Fig. $3 a$ ). In contrast, the appearance of VHR transformants was much slower and reached only about I \% of the maximum after $5 \mathrm{~min}$. of exposure. The level of HR and VHR transformants, however, both reached a plateau at 20 min. exposure. These results indicate that uptake and/or integration of the HR marker by itself precedes in time uptake and/or integration of HR along with the enhancing modifier. The reason for this time differential is unknown at the present time.

Fig. $3 b$ shows the results obtained with SR 5a DNA. As expected, the curves for transformants selected on 0.1 and $30 \mathrm{mg} . / \mathrm{ml}$. of streptomycin were the same. There was an initial rapid rise in transformants in which a plateau was again reached at $20 \mathrm{~min}$. exposure.

Frequency of HR and VHR transformants as a function of time allowed for phenotypic expression. These experiments were carried out in order to determine whether the differences in the levels of HR and VHR transformants from SR 30 DNA are due to differences in time of phenotypic expression. Competent cells were exposed to I $\mu \mathrm{g}$./ $\mathrm{ml}$. of DNA for $15 \mathrm{~min}$. DNase was added, then samples taken at intervals during incubation and plated on media containing $0 . \mathrm{I}$ and $30 \mathrm{mg}$. $/ \mathrm{ml}$. of streptomycin.

With SR 30 DNA (Fig. 4), there is an almost immediate expression of the HR marker with the maximum occurring after 60 to 80 min. incubation. In contrast, VHR transformants were not detected until after $60 \mathrm{~min}$. of incubation with the maximum occurring at $\mathrm{I} 20 \mathrm{~min}$. The ratio of HR to VHR transformants did not change significantly upon further incubation from $\mathrm{I} 20$ to $240 \mathrm{~min}$. Thus a difference in time for maximal expression cannot account for the greater frequency of HR over VHR transformants, since $120 \mathrm{~min}$. was allowed for the phenotypic expression of streptomycin resistance. Furthermore, the increased ratio of HR to VHR transformants during early expression is not surprising since it has been shown that more time is required for maximal expression of higher levels of streptomycin resistance than is required for lower levels (Rotheim \& Ravin, 196I). As a basis of comparison, similar experiments were performed with SR 5a DNA (Fig. 5). In the early stages of expression, the curves for SR 5a DNA were similar to those depicting the appearance 
of SR 30 HR and VHR transformants. That is, SR 5a transformants surviving $0.1 \mathrm{mg}$./ $\mathrm{ml}$. streptomycin appeared rather rapidly, reaching a maximum after 60 to $80 \mathrm{~min}$. incubation. On the other hand, SR 5a transformants surviving $30 \mathrm{mg} . / \mathrm{ml}$. of streptomycin were somewhat slow in appearing and did not attain a maximum until after $120 \mathrm{~min}$. Replica plating of the SR 5a transformants which appeared on $0 . \mathrm{I} \mathrm{mg}$.-streptomycin plates to $30 \mathrm{mg}$. streptomycin plates revealed transformants solely of the VHR phenotype.

Transformability of SR $5 a$ and $S R 30$ transformants. Since loss of transformability was of major importance in these studies, it was of interest to determine whether

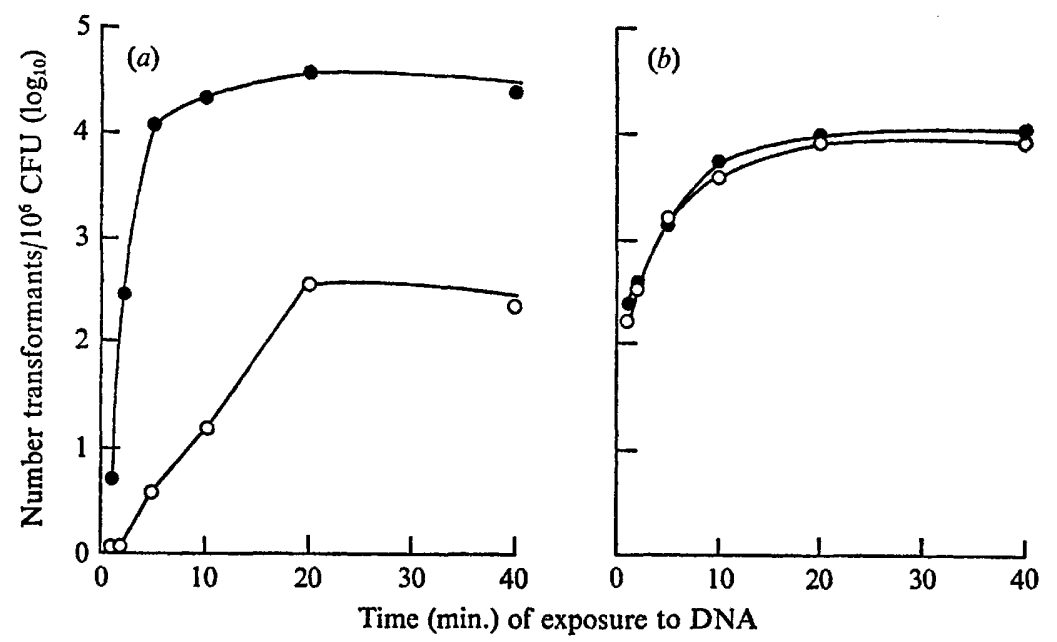

Fig. 3. Frequency of transformation of strain cHALLIS as a function time of exposure to DNA (I $\mu \mathrm{g}$./ml.). (a) SR 30 DNA. (b) SR 5a DNA. $\bullet$, Cells plated on $0.1 \mathrm{mg} . / \mathrm{ml}$. of streptomycin; $O$, cells plated on $30 \mathrm{mg} . / \mathrm{ml}$. of streptomycin.

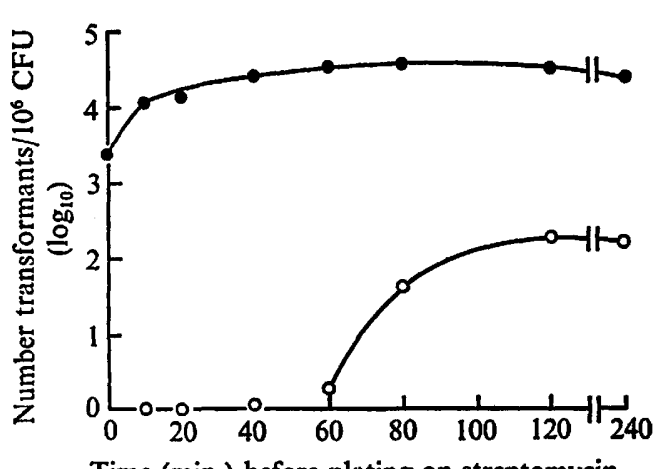

Time (min.) before plating on streptomycin

Fig. 4

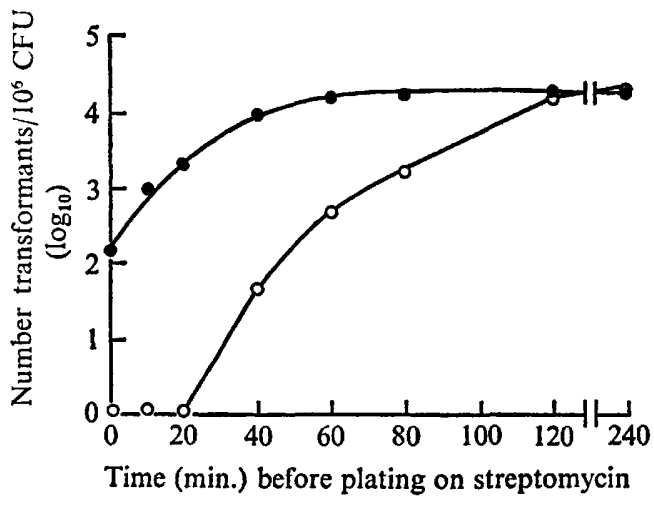

Fig. 5

Fig. 4. Transformation of strain CHALLIS by SR 30 DNA (I $\mu \mathrm{g} . / \mathrm{ml}$.) as a function of time of incubation before selective plating. 9 , Cells plated on $0.1 \mathrm{mg} . / \mathrm{ml}$. of streptomycin; $O$, cells plated on $30 \mathrm{mg} . / \mathrm{ml}$. of streptomycin.

Fig. 5. Transformation of strain CHALLIS by SR 5 a DNA (I $\mu \mathrm{g} . / \mathrm{ml}$.) as a function of time of incubation before selective plating. 0 , Cells plated on $0 . \mathrm{I} \mathrm{mg} . / \mathrm{ml}$. of streptomycin; $O$, cells plated on $30 \mathrm{mg} . / \mathrm{ml}$. of streptomycin. 
this property itself could be transferred by DNA. SR 30 HR and VHR transformants and SR 5a transformants (VHR) were isolated from the appropriate streptomycin plates and tested for transformability using CHALLIS DNA containing a novobiocin resistance marker. With respect to transformation to novobiocin resistance, the isolates were classified as transformable, $\operatorname{Tr}$ (average transformation frequency $\mathrm{IO}^{-3}$ ) and non-transformable, Ntr (frequency of transformation less than $\mathrm{IO}^{-5}$ ). As shown in Table 3, of Ioo isolates tested from the cross CHALLIS $\times$ SR $5 \mathrm{a}$ all were of the Tr class. Although one-half of these isolates were obtained from plates containing $0.1 \mathrm{mg} . / \mathrm{ml}$. streptomycin, all were found to be of the VHR phenotype when replicated onto $30 \mathrm{mg}$. streptomycin plates.

Table 3. Transformability of strain CHALLIS after exposure to DNA from mutant SR 5 a or SR 30

\begin{tabular}{lccr}
$\begin{array}{c}\text { Transformability } \\
\text { (novobiocin }\end{array}$ & $\begin{array}{c}\text { CHALLIS } \times \text { SR5a* } \\
\text { Transformant } \\
\text { phenotype } \\
\text { VHR }\end{array}$ & \multicolumn{2}{c}{$\begin{array}{c}\text { CHALLIS } \times \text { SR } 30^{*} \\
\text { Transformant }\end{array}$} \\
phenotype
\end{tabular}

* Competent CHaLlis cells were transformed with I $\mu \mathrm{g} . / \mathrm{ml}$. of DNA from mutant SR 5a or SR 30 and plated on medium containing $0 . \mathrm{I}$ and $30 \mathrm{mg} . / \mathrm{ml}$. of streptomycin. The phenotype of all transformants was verified by replica plating. One-half of the SR 5a transformants (VHR) were isolated from $0.1 \mathrm{mg}$. streptomycin plates.

$\dagger$ The transformability of all isolates was tested with $5 \mu \mathrm{g}$. $/ \mathrm{ml}$. of DNA from a novobiocin-resistant CHALLIS strain.

$\operatorname{Tr}=$ Transformable. Ntr $=$ Non-transformable.

In the case of SR 30 transformants, both classes of isolates were detected (Table 3) Among the HR transformants, 76 were Tr and 24 were Ntr while the distribution of Tr and Ntr among the VHR transformants was 82 and 18 , respectively. It is notable that similar numbers of Ntr transformants were found among both HR and VHR transformants. It should be remembered, however, that the frequency of all VHR transformants appearing was approximately $\mathrm{I} \%$ of the total number of HR transformants (Table I). Therefore, the actual frequency of VHR/Ntr $(=\mathrm{HR} /$ enhancing modifier/Ntr) transformants was only $0.18 \%$ of the total transformant population as compared to $24 \% \mathrm{HR} / \mathrm{Ntr}$ transformants. Thus $\mathrm{Ntr}$ is more frequently transferred with the HR marker than with the enhancing modifier.

Several hundred colonies from sensitive strain CHALLIS have been examined and all were found to be highly transformable. Hence, the Ntr factor must be carried on the SR 30 DNA and is not simply distributed among the sensitive recipient cell population.

\section{DISCUSSION}

The origin of streptomycin resistance mutations in transformable mutant SR 5a and non-transformable mutant SR 30 is different. In the case of mutant SR 5a, VHR probably occurred in a single step, whereas in mutant SR 30, VHR is due to at least two events-the acquisition of an HR mutation and the acquisition of an enhancing modifier gene mutation. Results (not shown) also indicate that the mutation conferring very high resistance in mutant SR 5 a is allelic with the HR mutation conferring resist- 
ance in mutant SR 30. This was determined by treating strain CHALLIS with DNA derived from a VHR transformant selected from the cross SR 30 HR transformant $x$ SR 5a. The resulting transformants were all of the VHR phenotype, thus indicating that the SR 5a VHR mutation had replaced the SR 30 HR mutation in the original cross.

The genetic factors responsible for different levels of streptomycin resistance are separable from that controlling transformability. Non-transformability is not obligatorily associated with either the streptomycin resistance marker or the enhancing modifier since $76 \%$ and $82 \%$ of the HR and VHR transformants, respectively, were transformable (Table 3). It appears likely, however, that $\mathrm{Ntr}$ is transferred more often with the HR marker than with the enhancing modifier (as measured by the VHR phenotype). Although the aquisition of Ntr probably arose independently of the streptomycin resistance mutations, the association of this factor with the HR marker permits its detection in transformation experiments. The presence of Ntr in SR 30 cells causes an inhibition of DNA uptake (Perry, 1968) which is at least partly due to an alteration in cell wall composition (D. Perry, unpublished data). That such a factor(s) can be transferred and followed by DNA would appear to offer an additional tool for studying the mechanisms of transformability.

The author gratefully acknowledges the valuable technical assistance of Mrs Sheila N. Prachand and the interest and helpful advice of Arnold W. Ravin.

This investigation was supported by Public Health Service grant AI 07694 from the National Institute of Allergy and Infectious Diseases.

\section{REFERENCES}

Bryan, B. E. (196I). Genetic modifiers of streptomycin resistance in Pneumococcus. Journal of Bacteriology 82, 46I-470.

Ephrati-ElizUR, E. (1965). Resistance to actinomycin D and transformability in B. subtilis. Biochemical and Biophysical Research Communications $\mathbf{x}$, 103-107.

Fox, M. S. \& Hotchkiss, R. D. (1957). Initiation of bacterial transformation. Nature, London, I79, I322-I 325 .

GoodGal, S. H. (196I). Studies on transformation of Haemophilus influenzae. IV. Linked and unlinked transformations. Journal of General Physiology 45, 205-228.

Lederberg, J. \& Lederberg, E. M. (I952). Replica plating and indirect selection of bacterial mutants. Journal of Bacteriology 63, 399-406.

OKubo, S. \& Romig, W. R. (1966). Impaired transformability of Bacillus subtilis mutant sensitive to mitomycin C and ultraviolet radiation. Journal of Molecular Biology 15, 440-454.

PAKula, R. \& WalczaK, W. (1963). On the nature of competence of transformable streptococci. Journal of General Microbiology 31, 125-133.

PERRY, D. (I968). Transformability of streptomycin-resistant group H streptococci. Journal of Bacteriology 95, I32-1 38 .

Ravin, A. W. \& DE SA, J. D. H. (1964). Genetic linkage of mutational sites affecting similar characters in Pneumococcus and Streptococcus. Journal of Bacteriology 87, 86-96.

Ravin, A. W. \& Mishra, A. K. (1965). Relative frequencies of different kinds of spontaneous and induced mutants of pneumococci and streptococci capable of growth in the presence of streptomycin. Journal of Bacteriology 90, I I6I-I I 73.

Rotheim, M. B. \& RAVIN, A. W. (I96I). The mapping of genetic loci affecting streptomycin resistance in Pneumococcus. Genetics 46, 1619-1634.

SirotnaK, F. M., LUNT, R. B. \& HutChison, D. J. (1963). Alteration in transformability of Diplococcus pneumoniae after the acquisition of genetic determinants inducing resistance to erythromycin. Journal of Bacteriology 86, 735-739.

Young, F. E. \& SPIZIZEN, J. (I96r). Physiological and genetic factors affecting transformation of Bacillus subtilis. Journal of Bacteriology 81, 823-829. 